\title{
Transition of Leptin Receptor Expression during Pubertal Development in Female Rat Pituitary
}

\author{
FUMI SHIMIZU, TOSHIYA MATSUZAKI, TAKESHI IWASA, NAOKO TANAKA, MASAHIRO MINAKUCHI, \\ AKIRA KUWAHARA, TOSHIYUKI YASUI, HIROYUKI FURUMOTO AND MINORU IRAHARA
} Department of Obstetrics and Gynecology, Institute of Health Biosciences, The University of Tokushima Graduate School, Tokush-
ima 770-8503, Japan

\begin{abstract}
Leptin is thought to play important roles in pubertal development and reproductive function in the female. Leptin receptor is expressed in various tissues including the pituitary and hypothalamus. We investigated the transition of leptin receptor (Ob-R) expression in female rat pituitary during pubertal development. Real-time RT-PCR was performed for long-form leptin receptor $(\mathrm{Ob}-\mathrm{Rb})$ and short-form leptin receptor $(\mathrm{Ob}-\mathrm{Ra})$ in the pituitary and cerebrum of the rats aged 4 (juvenile), 6 (pubertal), and 8 weeks (adult). Double immunohistochemical colocalization of Ob-R and luteinizing hormone (LH) was performed in pituitaries from 4-week-old female rats. Serum leptin concentrations of 4-, 6-, and 8week-old rats were measured by radioimmunoassay. In the pituitary, expression of Ob-Rb mRNA in 4-week-old rats $(1.00 \pm 0.16)$ was significantly higher than in 8-week-old rats $(0.61 \pm 0.07, \mathrm{p}<0.05)$, although expression of $\mathrm{Ob}$-Ra mRNA did not differ among 4-, 6-, and 8-week-old rats. In cerebrum, Ob-Ra and Ob-Rb mRNA expressions did not differ significantly among 4-, 6-, and 8-week-old rats. Intense staining of Ob-R and colocalization of Ob-R and LH were seen in 4-week-old rat pituitary. On the other hand, serum concentrations of leptin in 6- and 8-week-old rats were significantly higher than those in 4-week-old rats $(\mathrm{p}<0.05, \mathrm{p}<0.01$, respectively). In conclusion, since the pituitary gonadotroph is a potential target of leptin, the juvenile rat pituitary might prepare for a subsequent increase of serum leptin concentration by expressing $\mathrm{Ob}-\mathrm{Rb}$.
\end{abstract}

Key words: Puberty, Leptin receptor, Anterior pituitary, Gonadotropin

(Endocrine Journal 55: 191-198, 2008)

LEPTIN is a $16 \mathrm{kDa}$ polypeptide hormone encoded by the obese (ob) gene, that regulates food intake, body fat mass and energy expenditure [1]. It is well known that leptin also plays an important role in reproductive function [2,3]. There are numerous reports on the close relationship of leptin and puberty. In the human female, body weight and serum leptin concentrations increase with pubertal development, indicating a certain level of body fat mass is necessary for onset of puberty [4-7]. In animals, serum leptin levels have been

Received: May 4, 2007

Accepted: November 14, 2007

Correspondence to: Toshiya MATSUZAKI, M.D., Ph.D., Department of Obstetrics and Gynecology, Institute of Health Biosciences, The University of Tokushima Graduate School, 3-18-15 Kuramoto-cho, Tokushima 770-8503, Japan found to increase during the process of puberty $[4,7]$. Nutritional status is known to influence pubertal development in animals. Food restriction prevents vaginal opening in female rats, while leptin treatment reverses this delay [8]. Leptin treatment accelerates onset of puberty in normal female mice $[9,10]$. Thus, leptin seems to be a key factor in puberty. In vitro experiments revealed that leptin stimulates gonadotropin releasing hormone $(\mathrm{GnRH})$ release in cultured median eminence tissue including arcuate nucleus of male rats [11], and also stimulates gonadotropin secretion in cultured pituitary cells of male and female rats $[7,11]$. We previously reported that leptin stimulated gonadotropin secretion and synthesis in cultured rat pituitary cells [7], and that the pituitary of juvenile rat is more sensitive to leptin in stimulating gonadotropins than those of pubertal and mature rats [12]. 
Leptin receptor was reported to be expressed in hypothalamus, pituitary, ovary and uterus [13-18]. Leptin receptor is expressed in anterior pituitary cells such as luteinizing hormone (LH), follicle-stimulating hormone (FSH), thyroid stimulating hormone (TSH) or growth hormone $(\mathrm{GH})$ secreting cells $[15,19,20]$. Leptin receptor (Ob-R) has five isoforms. Only the long-form leptin receptor, named $\mathrm{Ob}-\mathrm{Rb}$, has a long intracellular domain and activates the signal transducer and activator of STAT transcription proteins [2]. The other isoforms, called the short-form leptin receptors, lack an intracellular domain and their precise physiological roles remain to be determined, except for ObRa which might transport leptin through physiological barriers in the brain [21, 22]. There are few reports about the expression of leptin receptor mRNA during the postnatal period. In the rat hypothalamus, expression of Ob-Rb mRNA is low at birth and rises significantly throughout the postnatal period $[17,18]$. In the rat pituitary, Ob-Ra mRNA levels were highest in neonatal rats (postnatal day 4; PD 4) and fell throughout postnatal development till PD 22 in both sexes, while $\mathrm{Ob}-\mathrm{Rb}$ mRNA levels remained constant between PD 4 and 22 in both sexes. However, there is no report about leptin receptor expression during pubertal development. In this study, we investigated the transition of leptin receptor expression in female rat pituitary during pubertal development, from juvenile to mature period.

\section{Materials and Methods}

\section{Animals}

Female Wistar rats aged 4 (juvenile), 6 (pubertal) and 8 (adult) weeks were commercially obtained from Charles River Japan Co. (Yokohama, Japan). Body weights of juvenile, pubertal and adult female rats were 75-95, 130-180, and 170-200 g, respectively. Mature rats were decapitated at random phases of their estrous cycles. All experiments were scheduled at the day of arrival. All procedures were carried out in accordance with the guidelines established by the National Institutes of Health Guide for the Care and Use of Laboratory Animals and under the approval of Ethical Committee on animal research of the University of Tokushima.

\section{Experimental design}

Three experiments were conducted. In experiment (Exp) 1, female Wistar rats aged 4, 6 and 8 weeks were used as models for juvenile, pubertal and adult periods, respectively. Animals were sacrificed by decapitation under anesthesia using pentobarbital sodium $(40 \mathrm{mg} /$ $\mathrm{kg}$ body wt ip), and blood samples were collected for baseline hormone assessment for LH, FSH, estradiol $\left(E_{2}\right)$ and leptin. The cerebrum and pituitary were then removed immediately and real time quantitative PCR was performed for $\mathrm{Ob}-\mathrm{Ra}$ and $\mathrm{Ob}-\mathrm{Rb}$ mRNA expression.

In Exp 2, female Wistar rats aged 4 weeks were used for immunohistochemical study. Animals were sacrificed by decapitation under anesthesia using pentobarbital sodium, and pituitaries were collected and double labeling immunohistochemistry was performed in order to study colocalization for leptin receptor and $\mathrm{LH}$.

In Exp 3, effects of various factors on expression of $\mathrm{Ob}-\mathrm{Rb} \mathrm{mRNA}$ were tested in pituitary culture of anterior pituitary cells using 4-week-old female rats which were assumed to have high expression of $\mathrm{Ob}-\mathrm{Rb}$. $\mathrm{GnRH}$ (Wako Pure Chemical Industries, Ltd., Osaka, Japan), leptin (Wako Pure Chemical Industries, Ltd.), insulin (Wako Pure Chemical Industries, Ltd.), estradiol (Wako Pure Chemical Industries, Ltd.), GnRH antagonist (Sigma, St. Louis, MO, USA), inhibin A (National Institute for Biological Standards and Control, Hertfordshire, UK), growth hormone releasing hormone (GHRH) (Peptide Institute, Inc., Osaka, Japan) and nicotine (Wako Pure Chemical Industries, Ltd.) were chosen because of their relation to pubertal development. Nicotine was chosen because its chronic administration stimulates $\mathrm{Ob}-\mathrm{Rb}$ mRNA expression in rat hypothalamus [23]. These factors were added to culture medium at $10^{-7} \mathrm{~mol} / \mathrm{l}$ except for control, and cells were collected after $48 \mathrm{~h}$ of culture. Ob-Rb mRNA expression levels of individual groups were assessed by real time quantitative PCR.

\section{Measurement of hormones}

Blood samples were obtained by decapitation and centrifuged to collect plasma, and all plasma samples were stored at $-20^{\circ} \mathrm{C}$. Leptin, estradiol, FSH and $\mathrm{LH}$ concentrations in rat plasma were assayed using leptin RIA kit (Linco Research, St. Charles, MO, USA), Estradiol kits (Diagnostic Products Corp., Los Angeles, 
CA, USA), the rat FSH [ $\left.{ }^{125} \mathrm{I}\right]$ Biotrak Assay System with Magnetic Separation (Amersham Biosciences UK Ltd., Buckinghamshire, UK) and the rat LH $\left.{ }^{125} \mathrm{I}\right]$ Biotrak Assay System with Magnetic Separation (Amersham Biosciences UK Ltd.), respectively. Assay sensitivities were $0.5,20,1.6$ and $0.9 \mathrm{ng} / \mathrm{ml}$ for leptin, estradiol, FSH and $\mathrm{LH}$, respectively.

\section{Total RNA isolation, reverse transcription of RNA}

Animals were sacrificed by decapitation under anesthesia using pentobarbital sodium $(40 \mathrm{mg} / \mathrm{kg}$ body wt ip). After blood samples were collected, the cerebrum and pituitary were removed immediately. Total RNA was isolated in using a TRIzol ${ }^{\circledR}$ reagent kit (Invitrogen Corp., Carlsbad, CA, USA) and an RNeasy ${ }^{\circledR}$ mini kit (Qiagen GmbH, Hilden, Germany). Reverse transcription was performed using SuperScript ${ }^{\mathrm{TM}}$ III (Invitrogen Corp.) according to the manufacturer's instructions.

\section{Real-time Quantitative RT-PCR analysis}

Real-time PCR was performed using a PCR System 9700 (PE Applied Biosystems, Foster City, CA) with SYBR $^{\circledR}$ Green PCR Master Mix (PE Applied Biosystems) according to the manufacturer's instructions. Primer pairs for rat $\mathrm{Ob}-\mathrm{Ra}$ [22] were used as previously reported, and those for rat $\mathrm{Ob}-\mathrm{Rb}$ were designed using Primer3 software (http://frodo.wi.mit.edu/cgi-bin/ primer3/primer3_www.cgi). The primer sequences for rat Ob-Ra were sense 5'-ATG AAG TGG CTT AGA ATC CCT TCG-3', antisense 5'-TAC TTC AAA GAG TGT CCG CTC-3', and those for rat Ob-Rb were sense 5'-GGT TGG ATG AGT TTT GGA A-3', antisense 5'AGA CAG TGA GCT GGG AAT GG-3'. The expected PCR product sizes were 347 and 160 base pairs for $\mathrm{Ob}-\mathrm{Ra}$ and $\mathrm{Ob}-\mathrm{Rb}$, respectively. The primer sequences for $\beta$-actin were sense 5'-TCA TGA AGT GTG ACG TTG ACA TCC GT-3' and antisense 5'-CTT AGA AGC ATT TGC GGT GCA CGA TG-3' (Promega Co., Madison, WI). Real-time PCR conditions were as follows: initial denaturation at $95^{\circ} \mathrm{C}$ for $15 \mathrm{sec}$, followed by amplification for 50 cycles which consisted of denaturing step at $95^{\circ} \mathrm{C}$ for $10 \mathrm{sec}$, annealing step at $65^{\circ} \mathrm{C}$ as rat $\mathrm{Ob}-\mathrm{Ra}$ and $\beta$-actin and $64^{\circ} \mathrm{C}$ as rat $\mathrm{Ob}-\mathrm{Rb}$ for $30 \mathrm{sec}$, and extension step at $72^{\circ} \mathrm{C}$ for $30 \mathrm{sec}$. For analysis of the dissociation curve, samples were subjected to $95^{\circ} \mathrm{C}$ for $15 \mathrm{sec}, 60^{\circ} \mathrm{C}$ for $15 \mathrm{sec}$ and $95^{\circ} \mathrm{C}$ for 15 sec. Beta-actin was used as an internal control. Rela- tive value of expression in 4-week-old rats group was arbitrarily set at 1 .

\section{Double labeling immunohistochemistry}

Four-week-old female rats were anesthetized by pentobarbital sodium $(40 \mathrm{mg} / \mathrm{kg}$ body weight intraperitoneal administration) and decapitated. Pituitaries were rapidly removed and placed in optimum cutting temperature compound (Tissue $\mathrm{Tek}^{\circledR}$ ), frozen in liquid nitrogen. Ten $\mu \mathrm{m}$ sections of the pituitary were made on a cryostat. Sections were first incubated in goat polyclonal antibody against leptin receptor $(1: 100$; sc-1834, Santa Cruz Biotechnology, Santa Cruz, CA, USA) overnight at $4^{\circ} \mathrm{C}$. Sections were then treated with Polyclonal Rabbit Anti-Goat Immunoglobulin/ Biotinylated (diluted $1: 500$; E0466 Dako Japan, Kyoto, Japan) for $30 \mathrm{~min}$ at room temperature, followed by incubation in tyramide signal amplification solution according to the manufacturer's instructions (TSA ${ }^{\mathrm{TM}}$ Fluorescence System, Perkin Elmer, Boston, USA). Next, sections were incubated in rabbit polyclonal antibody against LH (diluted $1: 400 ; 5720-4009$, Biogenesis Ltd., England, UK) overnight at $4^{\circ} \mathrm{C}$, and were then treated with Texas $\operatorname{Red}^{\circledR}$ dye-conjugated AffiniPure Donkey Anti-Rabbit IgG (diluted 1 : 50; Jackson ImmunoResearch Laboratories, Inc., West Grove, PA, USA) for $30 \mathrm{~min}$. The sections were mounted using Vectashield ${ }^{\circledR}$ mounting medium (Vector Laboratories, Burlingame, CA, USA) and were examined under a fluorescence microscope, Olympus BX50 (Olympus, Tokyo, Japan).

\section{$O b-R b$ mRNA expression in primary culture of rat anterior pituitary cells}

Rat anterior pituitary cells were cultured as previously reported [12, 24]. Four-week-old female rats were decapitated, and the pituitaries were removed. Pituitaries were cut into small pieces and washed in Dulbecco's modified Eagle's medium (DMEM; Nissui Co., Tokyo, Japan). These pieces were subjected to enzymatic dispersion for $40 \mathrm{~min}$ at $37^{\circ} \mathrm{C}$ using $0.25 \%$ trypsin, and were then dissociated by pipetting with $0.2 \%$ pancreatin at $37^{\circ} \mathrm{C}$ for $1 \mathrm{~min}[11,12]$. Cells were seeded in DMEM containing $10 \%$ fetal bovine serum, plated on 96-well culture dishes (Falcon Plastics, Los Angeles, CA, USA) at a density of $10^{6}$ viable cells/well, and incubated for $48 \mathrm{~h}$ in culture medium alone (control) or 
culture medium containing 1 of 8 test compounds at $10^{-7} \mathrm{~mol} / \mathrm{l}$; GnRH, leptin, insulin, estradiol, GnRH antagonist, LHRH antagonist, inhibin A, GHRH, and nicotine. All hormones were dissolved in PBS buffer, and diluted to $10^{-6} \mathrm{~mol} / \mathrm{l}$ by culture medium; their final concentrations were adjusted to $10^{-7} \mathrm{~mol} / \mathrm{l}$ by adding one tenth volume of each well. Nothing was added from control wells. Cell cultures were maintained at $37^{\circ} \mathrm{C}$ in a humidified atmosphere of $5 \% \mathrm{CO}_{2}$.

After $48 \mathrm{~h}$ of culture, cells were collected using trypsin, and total RNA was isolated using RNeasy ${ }^{\circledR}$ micro kits (Qiagen $\mathrm{GmbH}$ ). Reverse transcription was done using SuperScript ${ }^{\mathrm{TM}}$ III (Invitrogen Corp.) according to the manufacturer's instructions. Expression of Ob-Rb mRNA was studied by real-time PCR quantitatively as described above. Beta-actin was used as an internal control. Relative value of expression in control was arbitrarily set at 1 .

\section{Statistical analysis}

Differences of mean values among the groups were analyzed using Student's unpaired $t$-test. $P$ values less than 0.05 was defined as statistically different. Data were described as mean \pm SEM.

\section{Results}

\section{Serum leptin, estradiol and FSH concentrations}

Table 1 shows endocrinological background of rats used in Exp 1. Serum concentrations of leptin, estradiol and FSH in 6-week-old rats and 8-week-old rats were significantly higher than those in 4 -week-old rats. The results were in accordance of previous reports and indi-

Table 1. Serum leptin, estradiol and FSH concentarations in female rat.

\begin{tabular}{|c|c|c|c|}
\hline & $4 \mathrm{wk}(\mathrm{n}=22)$ & $6 \mathrm{wk}(\mathrm{n}=26)$ & $8 \mathrm{wk}(\mathrm{n}=29)$ \\
\hline $\begin{array}{l}\text { Leptin } \\
\quad(\mathrm{ng} / \mathrm{ml})\end{array}$ & $0.75 \pm 0.07$ & $1.08 \pm 0.13 *$ & $1.26 \pm 0.13^{* *}$ \\
\hline $\begin{array}{l}\text { Estradiol } \\
(\mathrm{pg} / \mathrm{ml})\end{array}$ & $29.08 \pm 1.75$ & $43.69 \pm 4.59 * *$ & $42.32 \pm 3.44^{* *}$ \\
\hline $\begin{array}{l}\text { FSH } \\
(\mathrm{ng} / \mathrm{ml})\end{array}$ & $0.28 \pm 0.05$ & $0.67 \pm 0.07 * *$ & $0.97 \pm 0.12^{* *}$ \\
\hline
\end{tabular}

Values are expressed as mean \pm SEM. *: $\mathrm{p}<0.05$ (vs. $4 \mathrm{wk}$ ), **: p $<0.01$ (vs. 4 wk) cated that 4-, 6- and 8-week-old represented the juvenile, pubertal and mature developmental stages, respectively. Serum LH concentrations of the 3 groups were lower than the minimum detectable concentration.

\section{$m R N A$ expressions in pituitary and cerebrum}

We studied the expression of mRNAs of leptin receptors quantitatively in pituitary and cerebrum of different age female rats. Fig. 1 shows the expressions of $\mathrm{Ob}-\mathrm{Ra}$ and $\mathrm{Ob}-\mathrm{Rb}$ mRNA in female rat pituitary and cerebrum. In pituitary, expression of $\mathrm{Ob}-\mathrm{Rb}$ mRNA was significantly higher in 4-week-old rats $(1.00 \pm$ 0.16 ) than in 8-week-old rats (Fig. 1B, $0.61 \pm 0.07$, $\mathrm{p}<0.05$ ), although expressions of Ob-Ra mRNA were not significantly different among 4-, 6-, and 8-weekold rats (Fig. 1A). In cerebrum, Ob-Ra and $\mathrm{Ob}-\mathrm{Rb}$ mRNA expressions did not differ significantly among the groups (Fig. 1C, D). Relative high expression of pituitary $\mathrm{Ob}-\mathrm{Rb}$ mRNA in 4-week-old female rats suggests the physiological significance of leptin action in pituitary of juvenile period.

\section{Double labeling immunohistochemistry}

We focused on the gonadotroph because expression of Ob-Rb mRNA seemed to decrease as pubertal development. Localization of Ob-R (green) and LH (red) was compared in tissue sections of pituitary from 4week-old female rats. Ob-R-immunopositive cells and LH-immunopositive cells were evident in 4-week-old rat (Fig. 2A, 2B). Ob-R-immunopositive cells were colocalized with LH-immunopositive cells (Fig. 2C).

\section{Ob-Rb mRNA expression of cultured pituitary cells}

Ob-Rb mRNA expression in the pituitary decreased in accordance with pubertal development. We hypothesized that endocrinological factors which vary around puberty might influence $\mathrm{Ob}-\mathrm{Rb}$ expression. We used 4-week-old female rat pituitary for cell culture as it would highly express $\mathrm{Ob}-\mathrm{Rb}$. However, none of the factors influenced the expression of $\mathrm{Ob}-\mathrm{Rb} \mathrm{mRNA}$ in $48 \mathrm{~h}$ culture (Fig. 3 ).

\section{Discussion}

It has been reported that $\mathrm{Ob}-\mathrm{R}$ was expressed on the 


\section{Pituitary}

A

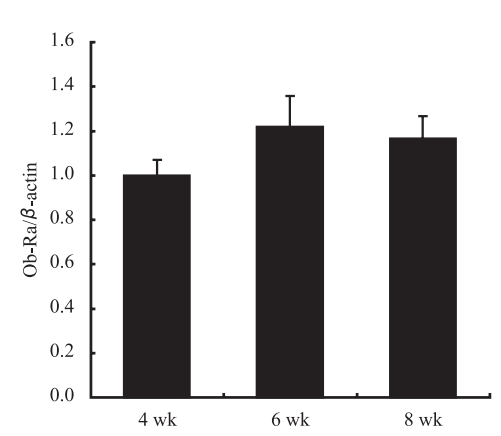

Cerebrum

C

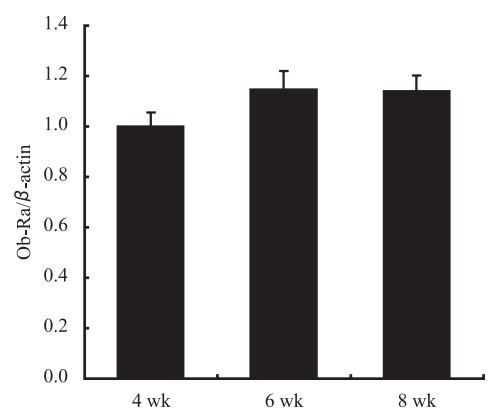

B

Ob-Rb

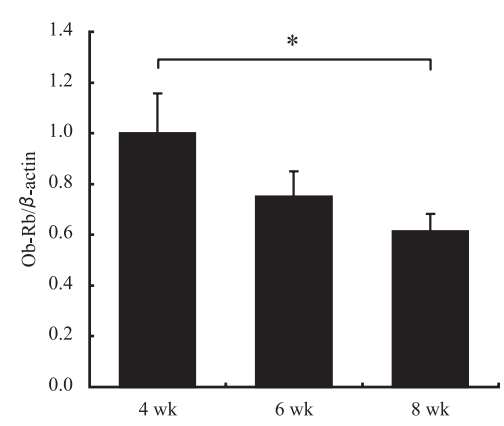

D

Ob-Rb

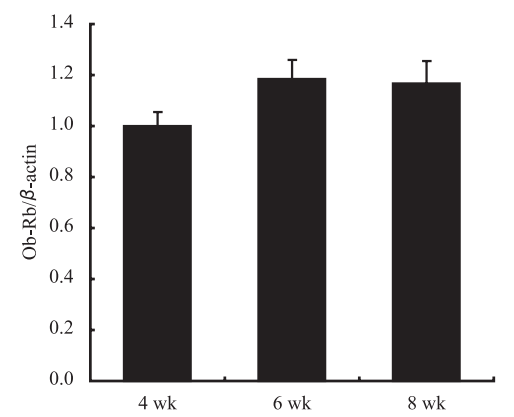

Fig. 1. Expressions of $\mathrm{Ob}-\mathrm{Ra}$ and $\mathrm{Ob}-\mathrm{Rb} \mathrm{mRNA}$ in female rat pituitary and cerebrum. Expression of Ob-Ra mRNA in pituitary did not significantly differ among the groups (A). On the other hand, expression of Ob-Rb mRNA in pituitary was significantly higher in 4-week-old rats $(1.00 \pm 0.16)$ than 8 -week-old rats $\left(0.61 \pm 0.07,{ }^{*} \mathrm{p}<0.05\right)$ (B). In cerebrum, expressions of both Ob$\mathrm{Ra}$ and $\mathrm{Ob}-\mathrm{Rb}$ mRNA did not differ among the groups $(\mathrm{C}, \mathrm{D})$. Each group comprised 12 samples $(\mathrm{n}=12)$. Values are expressed as means \pm SEM. Relative value of expression in 4-week-old rats was arbitrarily set at 1 .
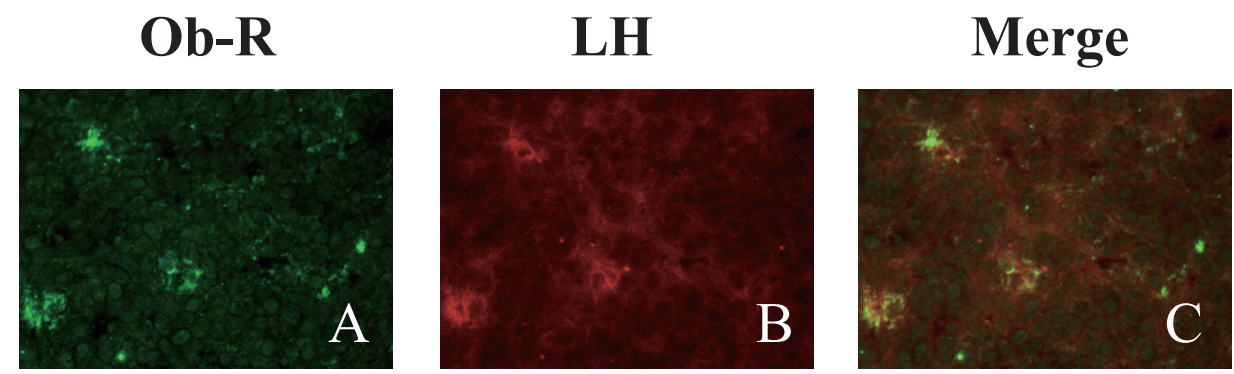

Fig. 2. Immunofluorescence photomicrographs $(\times 40)$ showing colocalization of leptin receptor $(\mathrm{Ob}-\mathrm{R})$ and $\mathrm{LH}$ in the female rat pituitary gland. (A) LH-positive cells, (B) Ob-R-positive cells, (C) merged image of A + B. Photomicrographs A-C depict samples from 4-week-old rat. LH-positive cells were colocalized with Ob-R-positive cells.

pituitary gonadotroph by immunohistochemistry [15, 17] and that leptin stimulates gonadotropin secretion directly [7,11]. Morash et al. reported that $\mathrm{Ob}-\mathrm{Rb}$ mRNA levels in the pituitary were constant between neonatal rats (postnatal day 4: PD 4) and juvenile rats (postnatal day 22: PD 22) [17]. In our study, we have shown that $\mathrm{Ob}-\mathrm{Rb}$ mRNA expression in the pituitary fell throughout pubertal development between juvenile period (4-week-old) and mature period (8-week-old) for the first time. By contrast, Morash et al. reported that Ob-Ra mRNA levels fell in the pituitary throughout postnatal development between PD 4 and PD 22, 


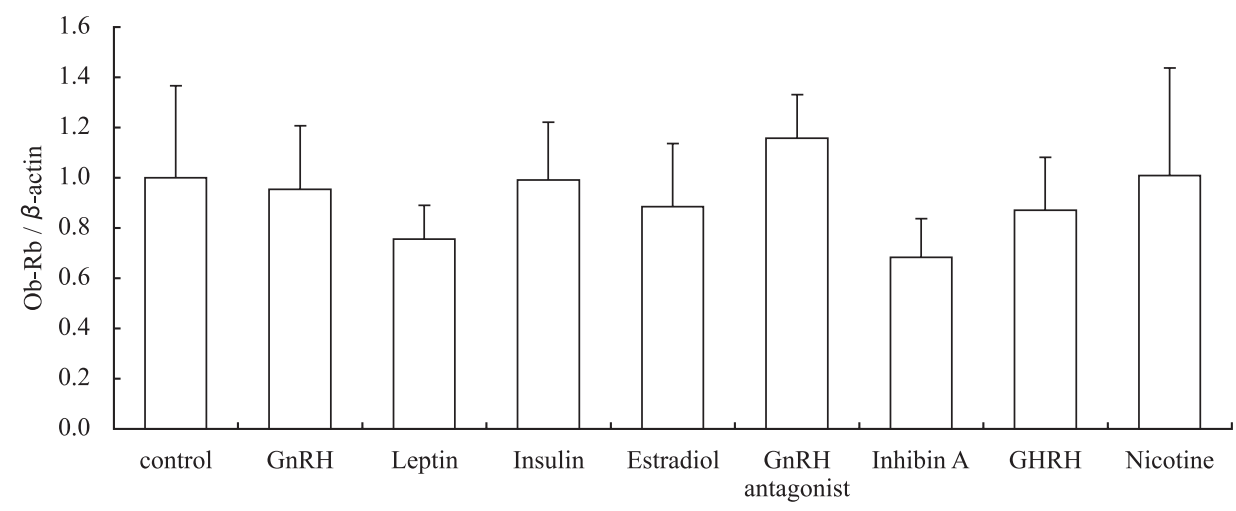

Fig. 3. Effects of various factors on expression of $\mathrm{Ob}-\mathrm{Rb} \mathrm{mRNA}$ in cultured rat anterior pituitary cells. No variations were apparent among the groups. Each group comprised 5 to 8 samples. Error bars indicate SEM. Relative value of expression in control was arbitrarily set at 1 .

while our data additionally revealed that $\mathrm{Ob}-\mathrm{Ra}$ mRNA levels were constant throughout pubertal development between 4- and 8-week-old rats [17]. Leptin receptors seems to be developmentally regulated in rat pituitary during not only the postnatal period described by Morash et al. but also the peripubertal period revealed by present study; that is, Ob-Ra expression would fall during the postnatal period while $\mathrm{Ob}-\mathrm{Rb}$ expression would fall during the peripubertal period. Colocalization of LH-staining and Ob-R-staining indicated leptin played an important role in gonadotrophs in juvenile period. On the other hand, serum leptin concentrations increased during development. It is assumed that $\mathrm{Ob}-\mathrm{Rb}$ mRNA expression in the pituitary was inversely associated with serum leptin concentrations throughout pubertal development. Therefore, it has been impossible to determine the physiological significance of leptin action on the pituitary in juvenile period because of the relatively low concentrations of serum leptin regardless of the high expression of its receptor. We previously reported that the most effective concentration of leptin on gonadotropin secretion was lower in juvenile rat pituitary cells than in pubertal and mature rat pituitary cells [12]. This means that juvenile rat pituitary cells were highly sensitive to leptin for secreting $\mathrm{LH}$ and FSH. However, it is inconceivable that serum gonadotropin concentration was elevated in juvenile period because of low concentrations of leptin and lack of pulsatile secretion of GnRH in this period. So, that juvenile rat pituitary might prepare for the subsequent elevation of serum leptin concentration which triggers onset of puberty.

Expressions of $\mathrm{Ob}-\mathrm{Rb}$ and $\mathrm{Ob}-\mathrm{Ra}$ in the cerebrum did not change during pubertal development in our study, although hypothalamic Ob-Rb expression reportedly increases from the fetal (gestational day 22) to prepubertal period (postnatal day 30 and 51), just prior to our observational period [25]. The role of hypothalamic $\mathrm{Ob}-\mathrm{Rb}$ would be mainly to monitor body energy storage through leptin signals, and to control appetite and energy expenditure. These systems would mature through development before juvenile period, hence $\mathrm{Ob}-\mathrm{Rb}$ expression was stable after the juvenile period. Hypothalamic $\mathrm{Ob}-\mathrm{Rb}$ has another role to stimulate GnRH secretion. Our results indicated that stimulatory leptin signals for GnRH secretion might not be modulated by changes in hypothalamic Ob-R expression during puberty, but mediated by ligand concentration.

There have been few reports on factors influencing the expression of $\mathrm{Ob}-\mathrm{Rb}$ mRNA except for nicotine which increases the expression of Ob-Rb mRNA in the hypothalamus [23]. We found relatively higher expression of $\mathrm{Ob}-\mathrm{Rb}$ mRNA in the juvenile rat pituitary and attempted to find factors which stimulated $\mathrm{Ob}-\mathrm{Rb}$ mRNA expression in cultured anterior pituitary cells from juvenile 4-week-old rats. However, no effect was seen on the expression of Ob-Rb mRNA after $48 \mathrm{~h}$ of incubation by the examined factors that exhibit changes in expression during puberty, such as leptin, estradiol and GnRH. This result might be due to experimental limitation such as concentrations of hormones and time of culture, or other factors that might be involved in $\mathrm{Ob}-\mathrm{Rb}$ expression.

In conclusion, our data indicated that $\mathrm{Ob}-\mathrm{Rb}$ expression in the female rat pituitary gonadotroph fell during pubertal development. Juvenile rat pituitary prepare 
for subsequent increase of serum leptin concentration by expressing $\mathrm{Ob}-\mathrm{Rb}$. Thus, the onset of puberty would be characterized not only by initiation of hypo- thalamic GnRH secretion but also gonadotropin secretion, both of which are stimulated by leptin.

\section{References}

1. Pelleymounter MA, Cullen MJ, Baker MB, Hecht R, Winters D, Boone T, Collins F (1995) Effects of the obese gene product on body weight regulation in $\mathrm{ob} / \mathrm{ob}$ mice. Science 269: 540-543.

2. Brann DW, Wade MF, Dhandapani KM, Mahesh VB, Buchanan CD (2002) Leptin and reproduction. Steroids 67: 95-104.

3. Moschos S, Chan JL, Mantzoros CS (2002) Leptin and reproduction: a review. Fertil Steril 77: 433-444.

4. Carlsson B, Ankarberg C, Rosberg S, Norjavaara E, Albertsson-Wikland K, Carlsson LM (1997) Serum leptin concentrations in relation to pubertal development. Arch Dis Child 77: 396-400.

5. Blum WF, Englaro P, Hanitsch S, Juul A, Hertel NT, Muller J, Skakkebaek NE, Heiman ML, Birkett M, Attanasio AM, Kiess W, Rascher W (1997) Plasma leptin levels in healthy children and adolescents: dependence on body mass index, body fat mass, gender, pubertal stage, and testosterone. J Clin Endocrinol Metab 82: 2904-2910.

6. Garcia-Mayor RV, Andrade MA, Rios M, Lage M, Dieguez C, Casanueva FF (1997) Serum leptin levels in normal children: relationship to age, gender, body mass index, pituitary-gonadal hormones, and pubertal stage. J Clin Endocrinol Metab 82: 2849-2855.

7. Ogura K, Irahara M, Kiyokawa M, Tezuka M, Matsuzaki T, Yasui T, Kamada M, Aono T (2001) Effects of leptin on secretion of $\mathrm{LH}$ and $\mathrm{FSH}$ from primary cultured female rat pituitary cells. Eur $J$ Endocrinol 144: 653-658.

8. Gruaz NM, Lalaoui M, Pierroz DD, Englaro P, Sizonenko PC, Blum WF, Aubert ML (1998) Chronic administration of leptin into the lateral ventricle induces sexual maturation in severely food-restricted female rats. J Neuroendocrinol 10: 627-633.

9. Ahima RS, Dushay J, Flier SN, Prabakaran D, Flier JS (1997) Leptin accelerates the onset of puberty in normal female mice. J Clin Invest 99: 391-395.

10. Yura S, Ogawa Y, Sagawa N, Masuzaki H, Itoh H, Ebihara K, Aizawa-Abe M, Fujii S, Nakao K (2000) Accelerated puberty and late-onset hypothalamic hypogonadism in female transgenic skinny mice overexpressing leptin. J Clin Invest 105: 749-755.

11. $\mathrm{Yu}$ WH, Kimura M, Walczewska A, Karanth S, McCann SM (1997) Role of leptin in hypothalamicpituitary function. Proc Natl Acad Sci USA 94: 10231028.
12. Tezuka M, Irahara M, Ogura K, Kiyokawa M, Tamura T, Matsuzaki T, Yasui T, Aono T (2002) Effects of leptin on gonadotropin secretion in juvenile female rat pituitary cells. Eur J Endocrinol 146: 261-266.

13. Zamorano PL, Mahesh VB, De Sevilla LM, Chorich LP, Bhat GK, Brann DW (1997) Expression and localization of the leptin receptor in endocrine and neuroendocrine tissues of the rat. Neuroendocrinology 65: 223-228.

14. Matsuda J, Yokota I, Tsuruo Y, Murakami T, Ishimura K, Shima K, Kuroda Y (1999) Development changes in long-form leptin receptor expression and localization in rat brain. Endocrinology 140: 5233-5238.

15. Sone M, Nagata H, Takekoshi S, Osamura RY (2001) Expression and localization of leptin receptor in the normal rat pituitary gland. Cell Tissue Res 305: 351356.

16. Morash B, Wilkinson D, Murphy P, Ur E, Wilkinson M (2001) Developmental regulation of leptin gene expression in rat brain and pituitary. Mol Cell Endocrinol 185: 151-159.

17. Morash BA, Imran A, Wilkinson D, Ur E, Wilkinson M (2003) Leptin receptors are developmentally regulated in rat pituitary and hypothalamus. Mol Cell Endocrinol 210: 1-8.

18. Smith JT, Waddell BJ (2003) Developmental changes in plasma leptin and hypothalamic leptin receptor expression in the rat: peripubertal changes and the emergence of sex differences. J Endocrinol 176: 313-319.

19. Jin L, Zhang S, Burguera BG, Couce ME, Osamura RY, Kulig E, Lloyd RV (2000) Leptin and leptin receptor expression in rat and mouse pituitary cells. Endocrinology 141: 333-339.

20. Lloyd RV, Jin L, Tsumanuma I, Vidal S, Kovacs K, Horvath E, Scheithauer BW, Couce ME, Burguera B (2000) Leptin and leptin receptor in anterior pituitary function. Pituitary 4: 33-47.

21. Tartaglia LA (1997) The leptin receptor. J Biol Chem 272: 6093-6096.

22. Smith JT, Waddell BJ (2002) Leptin receptor expression in the rat placenta: changes in ob-ra, ob-rb, and ob-re with gestational age and suppression by glucocorticoids. Biol Reprod 67: 1204-1210.

23. Li MD, Kane JK (2003) Effect of nicotine on the expression of leptin and forebrain leptin receptors in the rat. Brain Res 991: 222-231.

24. Kanematsu T, Irahara M, Miyake T, Shitsukawa K, 
Aono T (1991) Effect of insulin-like growth factor I on gonadotropin release from the hypothalamus-pituitary axis in vitro. Acta Endocrinol 125: 227-233.

25. Smith JT, Mark PJ, Waddell BJ (2005) Developmental increases in plasma leptin binding activity and tissue Ob-Re mRNA expression in the rat. J Endocrinol 184: 535-541. 